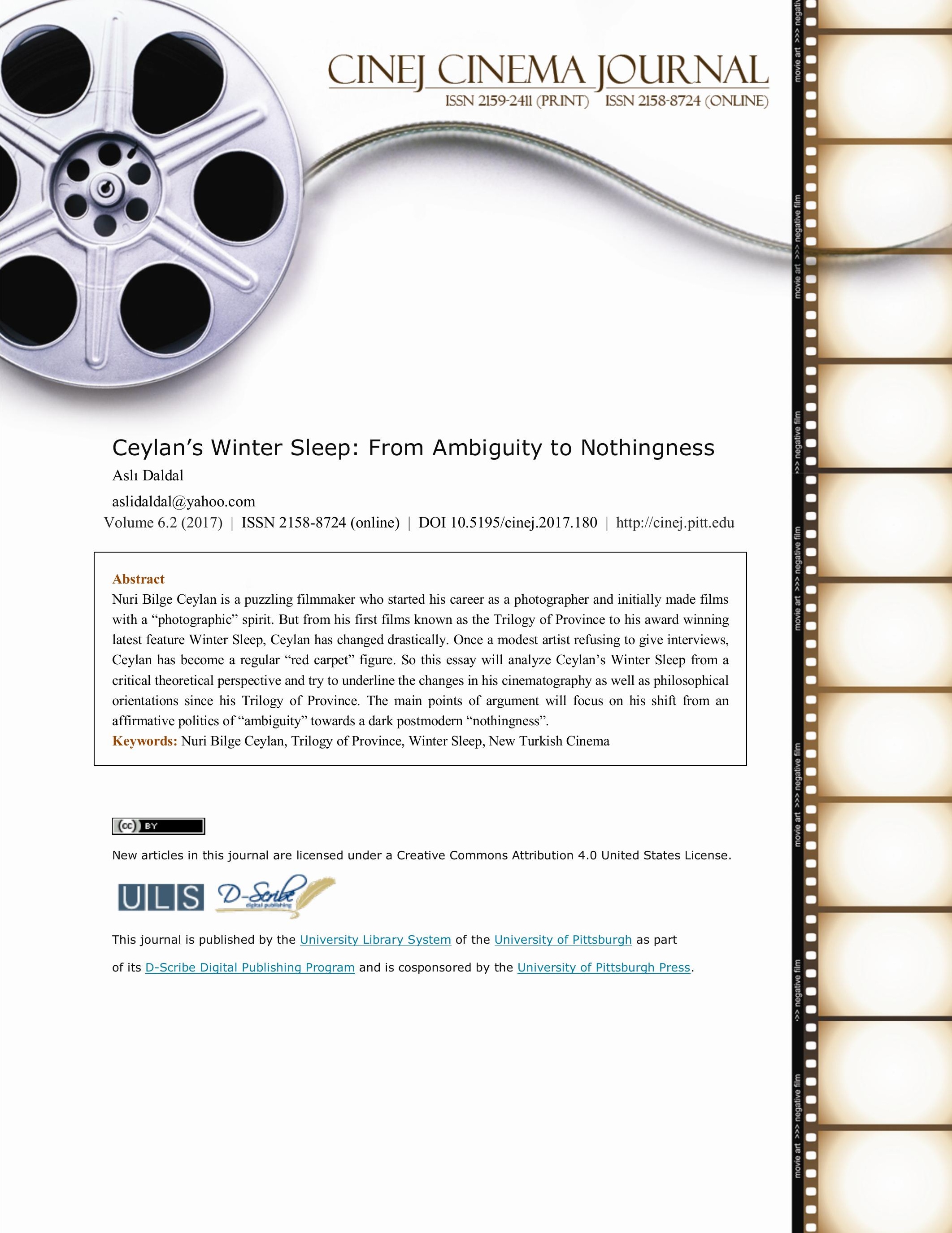




\section{Ceylan's Winter Sleep: From Ambiguity to Nothingness}

\section{Aslı Daldal}

One of the most outstanding filmmakers of the new Turkish Cinema who won an international acclaim through Cannes Film Festival such as Y1lmaz Güney, is Nuri Bilge Ceylan. Contrary to Güney, Ceylan, had very personal choices and refrained from getting popular in the initial stages of his directing career. In his "Trilogy of Province" composed of Kasaba (The Small Town 1997), Mayls Slkıntısı (The Clouds of May, 1999) and Uzak (Distant, 2002) he preferred a "minimalistic" cinema reminiscent of the Iranian filmmaker Abbas Kiarostami and the Japanese master Yasujiro Ozu's existential humanism. He was also influenced from the aesthetics of neorealism. Thus contrary to Güney's pronounced political tone, Ceylan borrowed neo-realism's phenomenological principles including "minimalism", “modesty" and "documentary verism"... But these were, of course, during the first "episode" of this enigmatic directors' filming career: Her was very shy, he refused giving interviews and refrained from meeting anyone "important" from the film industry. He was the "anti-director" who would challenge almost all the established norms of the filmic business. In his autobiographical film The Clouds of May which tells the shooting story of his previous film The Small Town, he explains how he does not want to deal with "all these snobbish people within the industry" and begs his elderly parents to play in his film. Ceylan's asceticism also included a form of "disgust" from "consumer society" and its "culture of abundance". Thus his minimalism was a new form of "political reaction to the present culture of excess" (Aliçavuşoğlu, 1999). Although not "political" in the traditional sense such as Y1lmaz Güney, Ceylan had, nevertheless, "political and social sensibilities" in an affirmative postmodern sense. He would never talk about the problems of the "working class", but would challenge the established norms of the "bourgeois" cinematography and the expectations of the audience. 
When we look at Ceylan's Winter Sleep (2014) which won -once again- the best film award at Cannes more than a decade after Distant, we see a surprisingly different Nuri Bilge Ceylan. Many filmmakers, certainly go through different stages in their directing careers and can adopt different, even contradictory, perspectives. But I believe Ceylan's case is really unique (as his initial cinematography) as he turned, in a sense, into his very "opposite", especially regarding his relations with this "snobbish" and "dirty" film industry. Once an ascetic artist refusing to give interviews, Ceylan has now become a regular "red carpet" figure and his fragile yet pertinent philosophical sensibilities are lost in a dark nihilism. So in this essay I will discuss Ceylan's Winter Sleep in comparison with his Trilogy of Province and underline his shift from an affirmative politics of "ambiguity" towards a dark postmodern "nothingness".

\section{The Trilogy of Province}

Ceylan's childhood was spent in Canakkale Yenice where his father worked as an agricultural engineer after his degree from US (a much debated issue in The Small Town-is it rational to go back to his native village after a degree from the US?). His happy childhood in Yenice has been very important for Nuri Bilge Ceylan and he referred to it over and over in his Trilogy of Province composed of Kasaba (The Small Town 1997), Mayıs Sikıntısı (The Clouds of May, 1999) and Uzak (Distant, 2002). The beautiful landscapes and nature of Yenice and his nostalgia for his lost childhood are recurrent themes of his earlier films. From Small Town to Distant all his films are almost exact autobiographical replicas of his agony and pain from getting away from this harmonious life within nature. Ceylan's quest for this childhood innocence was not limited to the plots of his films. Loathing all kinds of "fakeness", he refrained from engaging professional actors in his films. In his first trilogy, he casted his real family (his mother, father, cousin, wife etc.) as the main protagonists of the films. He gave almost no press interviews until 
Distant's unexpected success at Cannes. As he did not want to burden himself with bureaucratic details, he did not apply for financial support from the Ministry of Culture. So his initial films were made with unbelievably small budgets. Ceylan's initial films were very much reflecting (probably unconsciously) Siegfried Kracauer's "realist aesthetics" expanded in his voluminous Theory of Film written in 1960. A leading reporter of the Frankfurter Zeitung, Kracauer had a deep respect for cinema as the physical redemption of reality, and saw in it the first trumph of "content" over "form". Kracauer strongly held that the realm of the traditional arts was not adequate to understand cinema and a truly "cinematic approach" should be developed for this new and peculiar art. In fact, Kracauer in some sense despised the established arts and praised films "which incorporated aspects of physical reality with a view to making us experience them" (Kracauer, 1960, p.39). Kracauer also believed that the subject matter of cinema was the photographable world that gives itself naturally. He would also separate the "cinematic content" from the "uncinematic ones". For him, "content in the nature of subject matter is obviously cinematic if it pictures such elements of physical reality as the camera alone can capture" (Kracauer, p. 270). Capturing "the flow of life" was also essential for Kracauer as it was "a basic affinity of film, an emanation of the medium itself" (p. 273). In that sense for Kracauer the best filmic form was what he called a "slight narrative" where a very rudimentary story was at the background of a "life caught by the camera". In this form, acting, mise en scene and dialogue must be kept at a minimum not to overwhelm the visual content. Having a strong background in photography, Ceylan initially also embraced the Kracauerian notion that "the film is ontologically a continuation of photographic realism". Ceylan did not have developed plots but had basic themes enriched with stories found within simple details of everyday life. So in the Small Town, we are simply invited to feel and share the boredom of a young man who wants to leave his native village. We are also given the chance to contemplate the 
beautiful photographic details of life within this small town. In Clouds of May, Ceylan tells in a quasi ciné-verité fashion how he shot his previous film, the Small Town. The difficulties he had with his family while shooting the film, the impossibility of a healthy communication with the villagers and his father's deep passion for his land are the main themes of his second film. The harmony between man and nature plays a great part in Clouds of May contrary to Distant (the last film of the Trilogy) which reflects Ceylan's personal alienation within the big city and his total rupture from Yenice. In Distant set in Ceylan's own appartement at Cihangir Istanbul, two cousins, separated at the end of Clouds of May reunite, but this reunion turns into a power game between the hopeless young man from Yenice and his successful but unhappy elderly cousin. Even when rooted in a cinematic tradition of "realism" Ceylan's films always included a sense of “ambivalence" or "ambiguity" which was essential for artistic expression. Generally definable as "a lack of communication" or an inherent selfishness of human nature, this ambiguity has always been present in Ceylan's oeuvre which was (again) in line with Kracauerian notion of the “indeterminate”. Says Kracauer:

Natural objects, are surrounded with a fringe of meanings liable to touch off various moods, emotions, runs of inarticulate thoughts, in other words, they have a theoretically unlimited number of psychological and mental correspondances...Human faces are molded by inner experiences and the patina of old houses is a residue of what happened in them... Screen images tend to reflect the indeterminacy of natural objects. However selective, a film shot does not come into its own unless it incorporates raw material with its multiple meanings or what Lucien seve calls the "anonymous state of reality". (Kracauer, p.69)

In all the three films comprising the Trilogy of Province Ceylan uses the same stylistic techniques reminiscent of Kracauerian notions of "the flow of life" and the "indeterminate". Another source of inspiration in Ceylan's initial "minimalism" and "expressive realism" is, of course, Italian neo-realism. Like the masters of neo-realism, he prefers nonprofessional actors and (also in line with Y1lmaz Güney) he tries to truthfully reflect the surrounding physical reality. But 
contrary to Güney who, nevertheless, wished to give a certain subjective political direction to the viewers, Ceylan was obsessed with "minimizing the lie of cinema" (Özgüven, 2003, p.12). This wish to totally refrain from manipulating or deceiving the viewers pushed Ceylan to construct very minimal stories comparable to the innocent "slight dramas" of Abbas Kiarostami. As Ceylan also admits, for his "Trilogy of Province", the "slight narrative" cinemas of Yasujiro Ozu and Abbas Kiarostami were very important. Thus, until the making of Climates (2006) which signaled the end of Ceylan's “redemption of physical reality" Ceylan's cinematic universe included:

a) a deep passion for classic photography as the ontological source of realistic cinema. As mentioned above, we do not know if Ceylan was familiar with the work of Siegfried Kracauer, but his earlier films were good examples of Kracauerian notion of cinema as the "physical redemption of reality". Kracauer wrote that, as exemplified in many neorealistic films and also praised (with a somewhat different emphasis) by the French critic André Bazin, the "true" cinematic film should have a simple story, not overwhelming the visualization of physical reality. This story should have "permeability" which leaves room for spontaneity and continuity (the story should not "end"). It should be based on th earth (material existence) and the ordinary details of simple people. This is also a "contemplative cinema" in Hamid Dabashi's words in his Close Up Iranian Cinema, which reveals the "beauty in the benign brutality of being" (Dabashi, 2001, p.36).

b) a political tone in an apolitical guise. Contrary to Güney, or some neo-realist filmmakers such as Luchino Visconti or Guiseppe de Santis, Ceylan hardly talks about anything political. But by rejecting the present culture of consumption and excess through humble and slowly proceeding silent stories, by painfully trying to avoid the lie of cinema through minimal editing, sound, camera jobs and acting, by radically challenging the established norms of popular cinema through totally personal works, Ceylan is political in his first films, if not with "what" he says, but with "how" he says.

c) A background individualism and pessimism later to develop into total rupture from social action. Even in his earlier films praising harmony, nature and modesty, Ceylan is pessimistic about the possibility of true human solidarity. Compared to Kiarostami or the masters of neorealism, his characters are generally lazy and more selfish. The degree of this selfishness increases dramatically from The Small Town to Distant, and the former's rather humorous small human defects turn into variations of sadism in the latter. And from Climates (2006) onwards, Ceylan is 
carried away into new modes of nihilism which estrange him further from this childhood innocence he was once desperate to catch in cinema.

\section{Towards a Pessimistic Nihilism}

It is, of course, debatable whether the early films of Nuri Bilge Ceylan could be labeled as "postmodern". These films are "unique" in many ways, highly autobiographical and clearly bear the personal traits of an "auteur" filmmaker. Although lacking a "modernist" depth, these films believe in and thus "reveal" the physical reality that surrounds us. For these reasons it may not be appropriate to call them "postmodern" but I believe that, for the reasons I will try to elaborate below, from the Trilogy of Province to Winter Sleep Nuri Bilge Ceylan has increasingly moved towards a position that Pauline Marie Rosenau would call "Skeptical Postmodernism” (Roseanu, 1992, p.139). For Roseanu,

The skeptics embrace a political cynicism that is appropriate given their conception of modernity as a period of decay; the world as inevitably moving towards a final collapse, oblivion, and self-destruction that cannot be postponed. The skeptics ontological agnosticism urges them to relinquish any global political projects... They struggle to survive in a normative void (Rosenau, p.139)...

Nuri Bilge Ceylan has never been interested in politics in the classical sense of the word. Especially given the highly politicized and polemical nature of the Turkish filmmakers in the 60s and 70s (especially if we think about the polemics between the Neo-Kemalist social realists and the Marxists critics such as Onat Kutlar) he looked definitely very "apolitical". But as I tried to argue above, he nevertheless showed a certain "philosohical depth and social sensibility" by the filmic choices he made in his first films. The use of non-professional actors, a very conscious minimalist approach to storytelling were clear signs of a personal reaction to dominant filmmaking practices. But as Ceylan, himself, acknowledged in many interviews, he increasingly felt that, 
metaphysically speaking, "he was dying" and "loosing the sharpness of his senses" (Aliçavuşoğlu, 1999). So this feeling of decay and loss was, I believe, so permeable in all his films, that they were more than just films, but almost a cry for help, for rescue. In Distant, for example, when the photographer Mahmut tells his old pals that, "photography is dead", his friend (played by the famous photographer Arif Aşçı) reacts harshly, telling him that "man is born in himself and dies in himself" meaning that not photography but "Mahmut (aka Ceylan) was dying". And especially after the making of Climates (2006) following the actual death of Nuri Bilge Ceylan's cousin and lead actor Mehmet Emin Toprak at a car crash, Ceylan has gradually started to loose all contact with his past and childhood where he was still (metaphorically) alive. "Death" became a recurrent theme in his films either in the form of a presence of a physically dead or disappeared person (the father put in jail in Three Monkeys whose absence destroys the whole family, or the corpse of the dead man the police desperately searches for in Once Upon a Time in Anatolia) or a spiritual death, like the death of the "modern subject" with hopes, a precise belief and value system, a definable character. Although “ambiguity” has always been present in Ceylan's early filmic characters, some "good" or "identifiable" traits were nevertheless present in some of his protagonists, giving some "modernist" meaning and philosophical depth to his stories. In Distant, Yusuf, the unwanted cousing from Anatolia, was the antithesis of the selfish and alienated Mahmut. He was natural, kindred hearted and full of impossible dreams. In Winter Sleep which is, I believe, wrongly seen as a "kissing cousin" to Distant by some commentators (i.e. Howard Finnstein in Filmmaker) none of the characters are "definable" in the classical sense. It is impossible to bring any meaningful judgements upon their behaviors and never ending dialogues (apart from the idea that they are very "bored" and spiritually "lost") as they are all the time "good and bad" and "right and wrong" simultaneously. This situation brings the spectator to, what Fredric Jameson would call, the 
"waning of affect and historicity" as the lack of meaning (or the existence of too much meaning) result in a sense of individual "apathy" and "numbness". Borrowing another term from Fredric Jameson developed in his Postmodernism or the Cultural Logic of Late Capitalism, it is also possible to argue that in some of his later films, Nuri Bilge Ceylan's personal (as well as his protagonists') apathy and nihilism result in some kind of "pastiche". For Jameson "pastiche" is a postmodern phenomenon and it is a "soulless" imitation of an earlier style or subject. "Pastiche is, like parody, the imitation of a peculiar or unique idiosyncratic style, the wearing of a linguistic mask, speech in a dead language. But it is a neutral practice of such mimicry, without any of parody's ulterior motives" (Jameson, 1992, p.17). Would it be then possible to argue that, for example, Ceylan's Three Monkeys (2008) which won him the best director award at Cannes was a peculiar kind of "pastiche"? As an internationally acclaimed director Ceylan is hardly accused of such "blank imitations" but some Turkish critics, such as Agah Özgüç, harshly attacked him saying that he was simply copying Yılmaz Güney’s Father made in 1971 (Özgüç, 2014, p.104). Another well-known critic, Fatih Özgüven, in his article in Radikal, also said that the film was a “Bergmanized version of Güney's Father". Three Monkeys had real similarities with Güney's Father, in terms of the story (the poor man enters the jail for a crime he did not commit and the rich man who is really guilty courts the poor man's wife) but was totally devoid of the former's "class" emphasis. While Güney wanted to show the lack of conscience in the bourgeois class, Ceylan, maybe in a spirit of competition with fellow director Zeki Demirkubuz, wished to reveal an abstract notion of "guilt" and the "the devil in us". But strangely enough, although the similarity of the plot with Güney's film was very obvious, there was no single reference in Ceylan's film to the legendary Güney. Another "pastiche", this time, in Winter Sleep, is the "soulless" use of Chekhov and other famous writers in the extremely lengthy and totally "uncinematic" dialogues. These dialogue are said to be based on the works of Chekhov, Dostoyevsky and Shakespeare as, 
this time, openly expressed in the film and in various interviews by the director. Chekhov was a very much cherished writer for Ceylan and in the past, he often took "real" inspiration from the work of the master who, for Ceylan, was able to combine "tragedy and humour" (Suner, 2010, p.90). Clouds of May which had almost no "dialogue" was dedicated to Chekhov, this time for combining hope and despair in a setting where "nature" was the lead actor. Rekin Teksoy, a film critic and well known writer, emphasizes that Clouds of May is "unequaled in Turkish film history for its silent scenes reminiscent of Chekhov, its focus on the sounds of nature; its unpretentious, simple narration and its treatment of the natural world as a character on its own (Teksoy, 2008, p.122). When we come to the cold and unloving atmosphere of Winter Sleep, where the protagonists endlessly talk, almost like a "tautautolgy", about feelings and concepts that do not "really" speak to us at all (very much at odds with what Chekhov once meant for Ceylan and the audience), we can only feel a sense of "blank simulation" based on a Chekhovian deja vu.

In sum, it is possible to hold that "ambiguity" has always been present in Ceylan's works. Expressed differently by various writers and critics, Ceylan's initial cinematography did incorporate "contradictory" elements into a, nevertheless, familiar and "definable" existence. For Asuman Suner, the issue of "belonging", for example, was very crucial in the early films of Ceylan but the dilemma of "to leave or to stay?" (Suner, p.110) was never entirely solved. For Suner, "Ceylan's films never attempt to resolve the paradox of belonging; instead they playfully acknowledge the paradox" (p.111). After Climates, this affirmative acknowledgements of ambiguities turned into "abysses of meaning" in the sense Baudrillard uses for his theory of "implosion". This is especially true for Winter Sleep, "a film about everything and nothing" (Donadio, 2014) where the spectator is bombarded with contradictory meanings and messages like "the media messages that lead to social entropy" according to Baudrillard (Best and Kellner, 1991, 
p.121). This is a situation whereby "the apathetic masses (spectators) become a sullen silent majority in which all meaning, messages and solicitations implode as if sucked into a black hole" (Best and Kellner, p.121).

\section{Winter Sleep}

This film "about everything and nothing" according to its director, is set in the beautiful Cappadocia region of Turkey which literally means "the land of free horses". The allegory of "horse" is also an important motif throughout the film symbolizing many, and sometimes, contradictory points. The horse, first of all, symbolizes freedom and youth. The wild horses of Cappadocia runs freely in the valley of this legendary area like Timur (Mehmet Ali Nuroğlu), the young hotel guest who wishes to travel around the area with his motorcycle. Timur, like the horse he wishes to see, is young and boundless. But although symbolizing limitless youth and freedom (and also the youth of Nuri Bilge Ceylan who used to travel solo to faraway lands), Timur unwillingly pushes Aydın (Haluk Bilginer), the enigmatic hotel owner, to capture a wild horse and make it a domestic show item. When Timur leaves the hotel, refusing the comfort and fake friendliness offered by Aydın who lost his youth and mobility forever, the horse becomes the symbol of "captivity" as well as the latter's "conscience". Surrounded by unloving relatives and neighbors Aydın (which literally means "intellectual") ultimately releases the horse. But this act of conscience is only a momentary decision for Aydın who does not hesitate to shoot a rabbit, in a routine Sunday hunt, without any apparent remorse. This "anti-dialectics", where every thesis is contrasted to its "anti-thesis" without the traditional "synthesis" or "thelos" (or "meaning" in more plausible terms) is apparent throughout the film. Basically, the film tells the story of Aydin, a former actor, who runs a small hotel in the beautiful Cappadocia region. Although Aydin seems to have everything for a satisfactory life, he is constantly bothered by his divorced elderly sister Necla 
(Demet Akbağ) and unhappy young wife Nihal (Melisa Sözen). As the story unfolds with many dialogues between the protagonists, we learn that all the characters are some sorts of "captives" like the horse Aydın chases. Contrary to Ceylan's earlier films, the idea of "returning to Istanbul" is an "emancipatory" dream for all in the family. But as they all know that, nothing really awaits them in Istanbul, they do not take the necessary steps to get out of this prison. The sense of being physically stuck in this snowy village is complemented with the mental enslavement of the protagonists as they can never really communicate. In this "prison house of language", the characters also discuss some abstract philosophical issues without any apparent purpose. For example, Aydın's sister Necla puts forth a philosophical question concerning "resisting to the evil act". She says that if we do not resist to the evil doer, maybe we will give a chance to his or her conscience. Aydın mocks her sister's absurd idea and gives the obvious example of the "holocaust". Later, the sister and the young wife have a similar talk about "divorcing" and "leaving for Istanbul". Likewise Aydın and his wife argue in similar dead-end conversations. The only idea left behind these long and mostly repetitive dialogues in claustrophobic spaces is that, nothing is "real", "trustworthy" and "pure". Or maybe as Jonathan Romney says in Sight and Sound, some allusions to Sartre's Huis Clos, where "hell is others" (Romney, 2014). Of course Sartre's Huis Clos is an existential manifesto for freedom but not a fatalistic affirmation of "loneliness", whereas Ceylan's film is a Heidegerrian-Nietzschean remix that we are all "thrown into being". Some commentators, like Özen Nergis, hold that the existence of the poor family who lives in Aydın's house in the village as tenants can be seen as the possibility of a class based (or even political) analysis in the film:

Set in rural central Anatolia, Winter Sleep gives a critical figural role to class antagonism using the country and city trope, a recurrent motif in Ceylan's cinema... The urban-rural divide, complicated by divisions of 
class, is epitomized in the cartographic placement of the estate owner on a hill and the tenant way below...A landlord looking down on his subjects from the top of a hill, Aydin is a character between a disillusioned bourgeois in existential crisis and a wealthy man in pursuit of material and social capital, who ironically believes himself to be generous. The tenants who are locals of the town, however, do not get as much screen time. We learn very little of their lives (Nergis, 2014).

As Nergis also acknowledges, there is very little information about the lives of the tenants. They do indeed belong to a different class compared to Aydın and his family and the gap between the rich and the poor is likely to have a strong say in that confrontation. But it is not clear whether Ceylan has any real aim of engaging in class analysis in the "orthodox" sense of the word. Firstly, Ceylan never refers to anything political in his film or interviews. When asked about such expectations, Ceylan openly says that, "when I make a film I don't think about the current situation. The duty of a film-maker is not that of a journalist; the director should be more interested in the soul of the spectator" (Pulver, 2014). Contrary to Nergis, I believe that the hatred of the little Ilyas when he throws the stone to Aydin's car is more conditioned by "cultural" differences than "class" antagonisms. Ilyas who wants to become a "police" when he grows up, his sadomasochistic father who hits the boy without any pity and his religious uncle "Imam" Hamdi are not the typical representatives of a "working class" family. They are rather the paragons of the newly rising religious-nationalist Turkish middle class which forms the basis of the Justice and Development Party's (AKP) electorate. The cultural differences betwen Aydın's family and that of Ilyas is also apparent in their approach to the boy's aggressive behavior. Aydin who is educated in the Kemalist-western tradition says that they have to understand the boy's behaviour whereas the father quickly hits him. While writing his weekly columns, Aydın reflects in a quasi-satirical manner, the worries of the Kemalist elite in Turkey, now in minority position, vis a vis the uneducated majority mostly symbolized with the family of the religious man, "Imam" Hamdi. This 
rural family is also a way of reminding to Aydın's wife, Nihal, that a secular and emancipated woman is likely to be humiliated outside of her familiar circle even if she is rich. When Ilyas' father Ismail (Nejat İşler) throws to the stove the money Nihal brings them, he does not only save his honour. He also reminds to Nihal, and the female spectators, that they should not try to search for any kind of spiritual asylum outside of their traditional patriarchal shelter. It is certainly not a coincidence that the image of Nihal in tears of frustration is directly cut to her husband Aydin who could not go to Istanbul although he had promised so to her unloving wife. But here again, it is not possible to hold that Ceylan engages in a socio-political analysis of that "cultural clash", but simply expresses the impossibility of "real" empathy and communication.

As emphasized at the beginning of the essay, Ceylan is certainly an extraordinary director not only for his authentic approaches to filmmaking, especially in the initial phases of his career, but also for his unexpected change of attitude regarding the basic premises of his cinematographic choices. When we compare his Trilogy of Province with Winter Sleep we come across many striking differences. First of all, in terms of "cinematography", Winter Sleep is quite "uncinematic". Ceylan, once a succesful photographer as her elder sister Emine Ceylan, used to prefer long and photographic shots to visually deepen his filmic narratives. The depth of field was an important element in his films to enable the spectator to contemplate the mise en scene. This "cinema of contemplation" was especially visible in Clouds of May and Distant based on very few dialogues, letting the photographic images speak for themselves. Thus the camera work and the reality it catches were of primary importance for Ceylan, as discussed previously by the film theoretician Kracauer. The "speech-mad" Winter Sleep, on the other, has an extraordinary reliance on the spoken word reducing the physical reality and the camera work to simple "background motives". The result is a very "uncinematic" work very much at odds with Ceylan's past practices. 
As also emphasized by Kracauer, too much reliance on verbal statements increases a film's affinity for the theater:

Dialogue films either reproduce theatrical plays or convey plots in theatrical fashion. This implies that they automatically turn the spotlight on the actor, featuring him as an insoluble entity, and by the same token exile inanimate nature to the background. Most important, emphasis on speech not only strengthens this tendency away from camera-life but adds something new and extremely dangerous. It opens up the region of discursive reasoning, enabling the medium to impart the turns and twists of sophisticated thought, all those rational or poetic communications which do not depend upon pictorialization to be grasped and appreciated (Kracauer, 1960, p.104).

Those who prefer a "pure cinematic" approach generally avoid too much reliance on verbal statements. Ceylan's most cherished filmmakers such as Yasujiro Ozu, Abbas Kiarostami or Andrey Tarkovski are all famous for their elaborate camera work and equilibrium between word and image. In Winter Sleep, Ceylan definitely upsets this balance and turns the movie into a "filmed theatre" or "literary text". Given the lack of creativity and "pastiche-like" quality of the written text based mostly on a personalized adaptation of Chekhov, Dostoyevski and Sheakespeare, Winter Sleep, I believe, gets entirely dry and prosaic. Jonathan Romney, in his review in Sight and Sound on Winter Sleep on 28 November 2014, also underlines that it is a very theatrical film and quite disappointing in many ways. Romney correctly stresses that for much of the time, the characters do little except talk at length in darkened rooms and the longer dialogues feel like transcribed chapters of a novel. Romney is quite surprised that a landscape photographer of considerable brilliance, Ceylan prefers to shoot the film mostly indoors.

There are, certainly, successful filmmakers who cannot reduce the role of the dialogue but still keeps a "cinematographic" spirit alive. The French Nouvelle Vague director Eric Rohmer is a good example. In his Moral Tales, the protagonists constantly speak of their thoughts and feelings 
adding a definite "literary" quality to the film but, contrary to Ceylan, Rohmer's characters (like Rohmer himself) are not socially isolated creatures. Thus the long and silent shots depicting the physical surrounding at the beginning of his films (as camera introductions to the philosophical inquiries) and the existence of a down to earth "meaning" in both the characters and their long discussions create a warm harmony between the physical environment and the protagonists' verbal expressions. When Rohmer says that he is not scared of being too close to life and he is trying to eliminate what still draws him away from it (Williams, 1980, p.253), he is referring to a long tradition in France mostly symbolized by the "phenomenological realism" of André Bazin and Amédée Ayfre that also put primary importance to the "redemption of physical reality" in cinema. Another striking difference between Ceylan's earlier films and Winter Sleep concerns the filmmaker's choice of actors. As stressed before, Ceylan had a peculiar approach to acting in his earlier films and, as he avoided all contacts with the film "industry", he preferred his close friends and family instead of real actors (Akser and Bayrakdar, 2014). The use of nonprofessionals is certainly not new in the history of cinema. The Italian neo-realists, for example, as a reaction to fascist star system and personality cult preferred to use amateurs in their films. Cesare Zavattini, the leading scriptwriter of Vittorio de Sica, openly said that it was time to tell everyone that they are the true heroes of their lives as well as of the films. For Zavattini, each member of the audience should understand that he was the true protagonist of life (Overbey, 1978, p.76). So from neo-realism onwards, casting nonprofessional has been an ethical as well as politico-aesthetic question. Pier Paolo Pasolini, when asked by Oswald Stack about his choice of Anna Magnani in Mamma Roma, said that he was not very satisfied by that choice and he never casted Magnani again. Pasolini explained that, as a director, the most important thing for him was to answer the question of "what is that person in real life?"(Stack, 1969, p. 49). So the choice of 
an actor, professional or not, determines the basic aesthetic and political qualities of a film as well as the film's relation with the world film markets. Ceylan, once an ascetic film maker who would not even bother to ask support from the Ministry of Culture, has become a permanent figure in Cannes' red carpeted world film market. As a corollary to this, Ceylan's choice of artists changed drastically. It was not only a matter of preferring professionals over amateurs and family members. It would, probably be appropriate, to hold that as his stories moved from "slight narratives" to theatrical or literary dramas, acting became more important and the use of professional artists became necessary. Therefore today, the problem in Ceylan's films is not just the use of professional people. Once an admirer of modesty and hidden talent, Ceylan has now started to cast, not just professional, but "famous" and "trendy" actors, some appearing in popular television shows, who mostly lost that "innocent" look Ceylan once admired so deeply. In Winter Sleep, apart from Haluk Bilginer's exquisite performance as Aydın, many lead artists simply "recite" the memorized chapters from the scenario. Demet Akbağ (as Necla), a popular Turkish comedian, is especially disappointing, as her well known face from light comedies and tv serials, now exposed to several esthetic surgeries, can hardly reflect the pain and isolation Ceylan has created for her part.

When referring to postmodern culture, Dick Hebdige says that "postmodernity is modernity without the hopes and dreams which made modernity bearable" (Hebdige, 1986, p.85). Ceylan's long and painful journey from the "slow" but "contemplative" Trilogy of Province to "speech-mad" but "nihilistic" Winter Sleep is evocative of Hebdige's formula. From his first feature films onwards, Ceylan has been criticized by mainstream film commentators for being too slow and boring. He had little box office success and except for a handful of festivals and film fanatics he was not very much appreciated. His films were, nevertheless, very "cinematic", "authorial" and full of an authentic (even anarchist) reaction against the dominant filmmaking 
practices. His initial films always had a sense of ambiguity or ambivalence that was "bearable" given that art is always "polisemic". When we move from the "ambiguous" but "optimistic" Trilogy of Province to Winter Sleep, we come across an "implosion of meanings" that signals the end of all "hopes" and possible "dreams" for the future. This is probably the reason why famous critic Fatih Özgüven chose the title "When Everything Dies" for his review of Winter Sleep in Radikal on 12th of June 2014. Conclusively, it is possible to hold that Ceylan's main protagonist Aydın in Winter Sleep appears to be a "skeptical postmodern" (like Ceylan himself) who, as

Rosenau says, "is anti-determinist, pro-individualist, even narcissistic; refusing all responsibility for what goes on in the society around him" (Rosenau, 1992, p.141).

\section{BIBLIOGRAPHY}

Akser, M., \& Bayrakdar, D. (Eds.). (2014). New Cinema, New Media: Reinventing Turkish Cinema. Cambridge Scholars Publishing.

Aliçavuşoğlu, E.(1999). Çehov Beni Isıtıyor: Nuri Bilge Ceylan'la Söyleşi. Cumhuriyet,

December, 2.

Dabashi, H. (2001). Close Up Iranian Cinema. London: Verso.

Donadio, R. (2014). A Director Holds Up A Mirror To Turkey. NY Times, Dec., 22, 2014. Online, www.nytimes.com/2014/12/23/movies/winter-sleep-a-nuri-bilge-ceylan-take-on-turkish-

life.html>. Accessed on 20 September, 2017.

Finnstein, H. (2014). Once upon a Time in Cappadocia: The Scaping of Winter Sleep. Filmmaker, Oct. 28, 2014. Online, <filmmakermagazine.com 88112-once-upon-a-time-in-cappadocia-thescaping-of-winter-sleep $>$. Accessed on 20 September, 2017.

Hebdige, D. (1986). Postmodernism and 'the other side'. Journal of Communication Inquiry, 10: 2.

Jameson, F. (1992). Postmodernism or the Cultural Logic of Late Capitalism. Duke University Press. 
Kellner, D. and Best, S. (1991). Postmodern Theory: Critical Interrogations. NY: Guilford Press. Kracauer, S. (1960). Theory of Film. Princeton University Press.

Nergis, Ö. (2017). Cine-ethics and Class Struggle: A Review of Palme d'Or Winner Winter Sleep. Potemkin Review. Online, $<$ www.potemkinreview.com/ozen-nergis.html $>$. Accessed on 25 September, 2017.

Özgüç, A.(2014). Türk Sinemasında İstanbul. Istanbul: Horizon International. Özgüven, F. (2008). Güzel, Yalnız ve Suçlu. Radikal, Oct. 23, 2008. Online< http://www.radikal.com.tr/yazarlar/fatih-ozguven/guzel-yalniz-ve-suclu-904694/ Accessed on 25, September, 2017.

Özgüven, F. (2014). Kış Uykusu: Her şey Ölünce. Radikal, June 12, 2014. Online< www.radikal.com.tr/yazarlar/fatih-ozguven/kis-uykusu-her-sey-olunce-1196717>. Accessed on 27 September, 2017.

Özgüven, F. (2003). Nuri Bilge Ceylan ile Kişisel Yolculuk. Yirmibir Mimarlık Dergisi, May, 2003.

Pulver, A. (2014). Nuri Bilge Ceylan Criticizes Turkish Government over Mine Disaster. The Guardian, May 17, 2014. Online,<www.theguardian.com/film/2014/may/17/cannes-2014-wintersleep-film-nuri-bilge-ceylan-turkey-mine-soma.> Accessed on 25 September, 2017.

Romney, J. (2014). Film of the Week: Winter Sleep. Sight and Sound, Nov. 28, 2014.

Online, <www.bfi.org.uk/news-opinion/sight-sound-magazine/reviews recommendations/filmweek-winter-sleep $>$ Accessed on 3 October, 2017.

Rosenau, P., M. (1992). Post-Modernism and the Social Sciences. Princeton University Press.

Stack, O. (1969). Pasolini on Pasolini. Indiana Univ. Press.

Suner, A. (2010). New Turkish Cinema. London: I.B. Tauris, 2010.

Teksoy, R. (2008). Turkish Cinema. Istanbul: Oğlak Yayınları.

Williams, C. (ed). (1980). Realism and Cinema. London: Routledge.

Zavattini, C. (1978) A Thesis on Neo-Realism. In D. Overbey (ed) Springtime in Italy: A Reader on Neo-Realism. Connecticut: Archon Books. 